\title{
Using Anti-Stress Substances and Zinc Spray Under Phosphoric Acid Fertigation to Grown Under Salinity Stress of Sunflower Plant (Helianthus
} Annuus L.)

\author{
Ayman H. I. Serag ${ }^{1}$, Ali K. Seadh ${ }^{1}$, Rania M. El-Samet ${ }^{2}$
}

\begin{abstract}
Two field experiments were conducted on saline clay soil in a split-split-plot design with four replicates. The main plots were arranged to study the effect of phosphoric acid applied with irrigation water ( without, $6 \mathrm{~L} \mathrm{ha} \mathrm{ha}^{-1}$ and $12 \mathrm{~L} \mathrm{ha}^{-1}$ ) where subplots were occupied to with or without the zinc spray Zn (at $13 \%$ chelated on EDTA), While the sub- subplots were occupied to anti-stress foliar which included Salicylic acid SA (foliar spraying of $0.01 \mathrm{mM}$ ), foliar spraying of calcium (at $10 \%$ chelated on EDTA) and Salicylic acid with calcium (foliar spraying of $0.01 \mathrm{mM}$ with foliar spraying of calcium at $\mathbf{1 0 \%}$ chelated on EDTA). Where the interaction between these treatments showed that using phosphoric acid (12 $\left.\mathrm{L} \mathrm{ha}^{-1}\right)$ acid with zinc spray (at $13 \%$ chelated on EDTA) and spraying both salicylic acid $(0.01 \mathrm{mM})$ and calcium (at $10 \%$ chelated on EDTA) together showed an effective effect on increasing growth, the yield of grains, oil content and salinity tolerance by reducing the concentration of sodium and chloride in the sunflower plant.
\end{abstract}

Keywords: Sunflower, phosphoric acid, zinc, salicylic acid, calcium.

\section{INTRODUCTION}

Without any doubt, salinity occupies the most fundamental importance stretches widely in the arid or semi-arid regions. Absolutely soil salinization repeatedly happens in the arid regions rather than other regions cause a lack of rainfall in these areas; thus, salt is doubled in the root zone. Statistically, one-fifth of all the planted soils is seriously damaged by salinity further, more regions are threatened via this danger also, (Rasool et al., 2013). Salinity stress evokes physiological processes disorders in plant cells and results in severe harm to the photosynthetic apparatus. Therefore, salinity lowers plant production quantity and quality (James et al., 2011). The sunflower plant enjoys modest salinity stress for tolerant Salinity (Connor Hall, 1997).

The sunflower (Helianthus annuus L.) plant is regarded as one the most primitive oilseed crops worldwide. Sunflower has gained a large spotlight to meet the escalated demand for crops oils (Dawood et al., 2012). Salinity stress significantly affects mineral accumulation in sunflower leaves as it escalates salt concentrations. Excessive salinity standards have caused continuous damages in sunflower yield and yield components (head diameter, seeds yield/ plant, weight of 100 seeds, oil, and protein \%) (Abd El- Hammeid and Sadak, 2020).

Zinc considers an imperative micronutrient for crop growth; it is regarded as a necessary component of carbonic anhydrase. It is also a motivator of aldolase that engages in carbon metabolism (Tsonev and Lidon, 2012). Furthermore, lack of Zinc displays a strategic physiological role in leaf chemistry structure and function, particularly under salt stress (Aktas et al., 2006). Many scientists note $\mathrm{Zn}$ as a promoter of plant drought tolerance through various mechanisms. It relieves drought stress by upgrading plant water relations, cell membrane stability, osmolytes concentration, stomata regulation, and water uptake. In addition, applying $\mathrm{Zn}$ increases internal hormones (auxins, gibberellins, and melatonin). It also enhances aquaporin and antioxidant system activities, which helps photosynthetic efficiency from significant mitigation of drought stress influences (Hassan et al., 2020).

Salicylic acid (SA) is studied as a tiny microscopic phenolic compound that is widely allocated in higher plants. Besides, SA has been acknowledged as a governed moderate clue in plant fences against varied stresses (Ali et al., 2014; Elkhatib et al., 2017). $\mathrm{Na}^{+}$and $\mathrm{Cl}^{-}$intake is extraordinarily diminished by $\mathrm{SA}$ foliar application at the level of $1.0 \mathrm{mM}(\mathrm{NaCl})$ (Noreen et al., 2013). (Noreen et al., 2017) remarked that the salicylic acid has affirmed a possible Phytoprotectant for declining salinity negative influences. Subsequently, physiological and biochemical features, stem length, and $\mathrm{K}^{+}$ion 
uptake are developed. In contrast, the plant system has defeated $\mathrm{Na}^{+}$and $\mathrm{Cl}^{-}$ions.

Phosphorus (P) is one of the best valuable macronutrients recommended for ideal plant growth and crop. Plants require it in the form of phosphate anions from soil solution. Moreover, it is regarded as one of the slightest applicable plant nutrients in the rhizosphere. Available phosphate obsession in soils is the dominant proof for its low availability (Raghothama and Karthikeyan, 2005). Soares et al., (2020) indicated that phosphorus fertilization enhanced sunflower agricultural components, $\mathrm{P}$ volume in leaf, achenes yield, and oil yield. Kaya et al., (2001) noted that phosphorus plays an avital role in relieving negative salinity results on the entire plant biomass for all kinds of crop plants. Phosphoric acid (PA) is a fluid fertilizer that is mainly applied to produce phosphatic fertilizers (Quader, 2009). Applying fluid $\mathrm{P}$ fertilizers have soil acidification outcome can improve crop yield in saline soils and make such soils better by declining their $\mathrm{pH}$ and SAR. PA is considered an appropriate source for this target according to its high solubility and access in the root zone by irrigation water (Hussain et al., 2011). Phosphoric acid includes much more phosphorus insolvable form other solid fertilizers; when roots absorb this available phosphorus, plant root becomes better, the improving uptake of macro and micronutrients. Conclusively the shoot biomass is escalated (Hussain et al., 2011). (Ameen et al., 2019) remarks that applying phosphoric acid promotes salts leaching, ultimately declining soil EC and SAR. Thus, phosphoric acid can be as a fertilizer and an excellent recovering agent in saline soils.
Calcium is a vital macronutrient that leads to essential physiological actions control in plants, contributing to cell walls and membranes strength. It is also diminishing cherry cracking (Wojcik et al., 2013). Under dryness conditions, growth and physiological performance are enhanced by $\mathrm{Ca}$ foliar (Xu et al., 2013). It is examined that calcium restricts $\mathrm{Na}^{+}$uptake and diminishes its negative consequences on seed germination (Bonilla et al., 2004). Declining salt toxicity on germination by $\mathrm{Ca}^{2+}$ has been applied in various crop plants like sunflower (Daowei and Moxin, 2010).

The objective of this study was conducted to study the possibility of increasing the resistance of sunflower plants to salinity in the northern delta in Egypt by using phosphoric acid, spraying with Zinc, salicylic acid and calcium to give an economic yield.

\section{MATERIALS AND METHODS}

\section{The experimental site and climate}

Two field experiments were conducted in two summer seasons (2017 and 2018) at El-Serw Agriculture Research Station, Agriculture Research Center, Damietta Governorate in Northern Egypt. At the start of the experiments, the analysis of the surface soil layer $(0$ to $30 \mathrm{~cm})$ was as follows: soil saturation extract for EC (ECe) was $8 \mathrm{dSm}^{-1}$ with $\mathrm{pH}$ value of 8.1 and contained $6.8 \mathrm{~g} \mathrm{~kg}^{-1}$ Walkley-Black organic carbon, $0.38 \mathrm{~g} \mathrm{~kg}^{-1}$ total nitrogen by the Kjeldhal method (Nelson and Sommers, 1980), $7.31 \mathrm{mg} \mathrm{kg}$ kg $^{-1} 0.5 \mathrm{M}$ NaHCO3-extractable P (Olsen et al., 1954) and $464 \mathrm{mg}$ $\mathrm{kg}^{-1} 1 \mathrm{~N}$ NH4OAc-extractable K (Jackson, 1967). Irrigation from El-Serw drain (EC ranged from 3.2 to3.3 $\mathrm{ds} \mathrm{m}^{-1}$, SAR 10.5:11.3). The date of climatic conditions are presented in Table (1).

Table 1. Average Precipitation $\left(\mathrm{mm} \mathrm{day}^{-1}\right)$, Surface pressure $(\mathrm{kPa})$, Relative Humidity $(\%)$ and Wind speed range $\left(\mathrm{m} \mathrm{s}^{-1}\right)$ of experimental site during summer seasons (2017 and 2018)

\begin{tabular}{|c|c|c|c|c|c|c|c|c|c|}
\hline & \multirow[t]{2}{*}{ Date } & \multicolumn{2}{|c|}{$\begin{array}{l}\text { Precipitation }(\mathrm{mm} \\
\left.\text { day }^{-1}\right)\end{array}$} & \multicolumn{4}{|c|}{$\begin{array}{l}\text { Relative Humidity at } 2 \text { Wind Speed at } 2 \text { Meters } \\
\text { Meters }(\%)\end{array}$} & \multicolumn{2}{|c|}{ Surface Pressure $(\mathrm{kPa})$} \\
\hline & & Mean & Std. Dev. & Mean & Std. Dev. & Mean & Std. Dev. & Mean & Std. Dev. \\
\hline \multirow{4}{*}{2017} & June & 0.00 & 0.00 & 52.44 & 6.88 & 4.11 & 1.16 & 100.97 & 0.21 \\
\hline & July & 0.00 & 0.00 & 56.39 & 4.06 & 4.12 & 1.11 & 100.73 & 0.17 \\
\hline & August & 0.00 & 0.00 & 58.89 & 3.96 & 4.17 & 0.76 & 100.92 & 0.18 \\
\hline & September & 0.00 & 0.00 & 58.23 & 3.41 & 4.07 & 0.98 & 101.23 & 0.24 \\
\hline \multirow{4}{*}{2018} & June & 0.49 & 2.44 & 54.93 & 4.26 & 4.05 & 1.16 & 101.08 & 0.20 \\
\hline & July & 0.09 & 0.34 & 55.84 & 3.75 & 3.82 & 1.04 & 100.69 & 0.24 \\
\hline & August & 0.00 & 0.00 & 57.53 & 3.06 & 3.96 & 0.78 & 100.83 & 0.15 \\
\hline & September & 0.00 & 0.00 & 58.99 & 3.74 & 3.51 & 0.99 & 101.23 & 0.21 \\
\hline
\end{tabular}




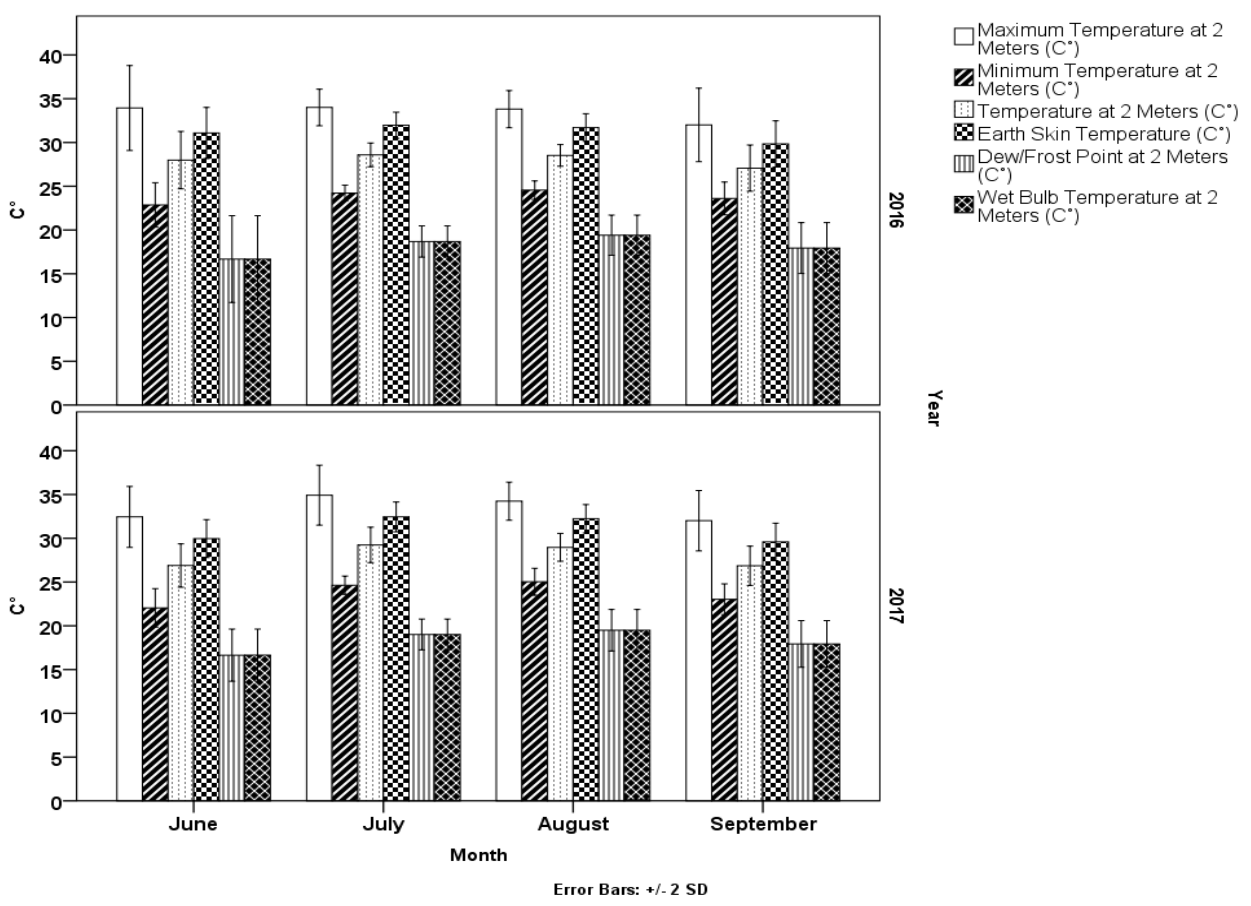

Fig. 1. Maximum, Minimum and main Temperature, Earth skin temperature Dew/Forest Point and Wet Bulb Temperature $\left({ }^{\circ} \mathrm{C}\right)$ of experimental site during summer seasons 2017 and 2018

\section{Treatments and crop management}

A split-split-plot design was used with four replicates, the main plots were arranged to study the effect of three phosphoric acid $\mathrm{H}_{3} \mathrm{PO}_{4} 80 \%$ levels i. e. without addition (P0), $6 \mathrm{~L} \mathrm{ha}^{-1}$ (P6) and $12 \mathrm{~L} \mathrm{ha}^{-1}$ (P12) were added with irrigation water after the seed thinning process and immediately before the formation of flowering buds of the sunflower plant. Phosphoric acid was added to irrigated water. While the subplots were occupied by with or without the zinc spray zn (at 13\% chelated on EDTA) $\mathrm{C}_{10} \mathrm{H}_{14} \mathrm{~N}_{2} \mathrm{O}_{8} \mathrm{Zn}$ was sprayed after the seed thinning process and before the formation of flowering buds of sunflower plants.

While the sub-sub plots were occupied to antistress as a foliar spray of Salicylic acid $\mathrm{C}_{7} \mathrm{H}_{6} \mathrm{O}_{3}$ SA $(0.01 \mathrm{mM})$ alone, Calcium as a form of $(10 \%$ chelated on EDTA), $\mathrm{C}_{10} \mathrm{H}_{14} \mathrm{~N}_{2} \mathrm{O}_{8} \quad \mathrm{Ca}$ alone and interaction between them, Anti-stress was sprayed after the seed thinning process and before the formation of flowering buds of sunflower plants.

The plot size was $16 \mathrm{~m}^{2}(4 \mathrm{~m} \mathrm{X} 4 \mathrm{~m})$ contained four ridges ( $4 \mathrm{~m}$ long and $50 \mathrm{~cm}$ apart). Sunflower (Helianthus annuus L.), Giza 102, was sown in the hill on June $5^{\text {th }}$. Seeds of sunflower were planted on $20 \mathrm{~cm}$ apart at one side in a hill. Thinning was achieved when 4-6 true leaves were formed (15-17 days from planting) to one plant per hill before the first irrigation in both seasons. Other agricultural practices were done as followed by farmers.

\section{Sunflower characteristics and crop yields}

Samples of five plants were taken randomly from the inner rows of each plot to measure plant height $(\mathrm{cm})$ and head diameter $(\mathrm{cm})$. The sunflower was harvested at maturity in the $2^{\text {nd }}$ week of September during both seasons. After the signs of maturity appear, the seeds are collected and weighed to obtain the crop yields $\mathrm{t} \mathrm{ha}^{-1}, 1000$ seed consider $\mathrm{g}$ and oil content.

Sodium (Na) \%, Chlorin (Cl) \% and oil content in sunflower plant.

To determine $\mathrm{Na}$ and $\mathrm{Cl}$ concentration in leaves, the fourth leaves from the top of the plant were sampled at harvest stage. Leaf sample was washed with distilled water, dried at $70{ }^{\circ} \mathrm{C}$ for $48 \mathrm{~h}$ (Chapman and Pratt, 1961). Oilseed content was determined using the Soxhlet method (A. O. A. C., 1980).

\section{Statistical analysis}

Data were statistically analyzed, and the standard error was determined. Mean values at levels of $(p<$ $0.05)$ and $(p<0.01)$ were compared using the LSD test. It was also used for variance analysis (ANOVA). According to (Snedecor and Cochran 1981). 


\section{RERSULTS AND DISCUSSION}

\section{Growth parameters:}

Table 2 illustrates the effect of phosphoric acid fertilization on mean plant height, head diameter, and its impact on pooled analysis during both seasons. Applying different rates of phosphoric acid resulted in a significant $(\mathrm{p}<0.01)$ influence on plant height and pooled plant height in the studied two seasons. Increasing rates of phosphoric acid caused progress in plant height and pooled plant height. Maximum plant height and pooled were recorded with $\mathrm{P} 12$ and P6 treatment, respectively. On the other hand, phosphoric acid application in both seasons didn't change head diameter and pooled head diameter $(\mathrm{p}>0.05)$.

Data shown in Table 2 displays a significant $(p<0.01)$ effect on plant height, pooled plant height, head diameter, and pooled head diameter by Zinc foliar application in both seasons. Using zinc foliar application resulted in highly significant values of the previous growth parameters compared without zinc foliar application in both seasons.

Table 2 indicates that there was a significant $(p<0.01)$ influence on sunflower growth parameters and pooled analysis (plant height, pooled plant height, head diameter, and pooled head diameter) by applying anti-stress foliar application.

The different anti-stress foliar influences on sunflower growth parameters and pooled analysis were ranked as a follow $\mathrm{SA}+\mathrm{Ca}, \mathrm{SA}$ and $\mathrm{Ca}$, respectively.

Data given in Table 2 demonstrate a significant interaction $(\mathrm{p}<0.01)$ among phosphoric acid fertilization, zinc foliar, and anti-stress foliar on sunflower plant height and pooled plant height. The highest values of plant height (Figure2) were gained with (application of $\mathrm{P} 12+$ zinc foliar + salicylic acid foliar with calcium foliar), (application of P6 + zinc foliar under salicylic acid with calcium foliar) and (application of P6 + salicylic acid with calcium foliar), respectively.

Phosphoric acid had significantly affected plant height by increasing it (Table 2). This could be caused by the absorption of available phosphorus by roots; plant roots become better; thus, other nutrients uptake improves. Conclusively the shoot biomass is escalated (Hussain et al., 2011). Also, Table 2 indicated that phosphoric acid had not significantly affected head diameter. Furthermore, applying Zinc foliar also increased the plant height and head diameter of the sunflower plant (Table 2). This could be due to applying $\mathrm{Zn}$ increasing internal hormones (auxins, gibberellins, and melatonin). It also enhances aquaporin and antioxidant system activities, which helps photosynthetic efficiency coming from significant mitigation of drought stress influences. (Hassan et al., 2020). In the same Table, plant height and head diameter were affected significantly by anti-stress foliar. Table 2 illustrated that salicylic acid had significantly affected in growth parameter of the sunflower plant. These results contribute to improving photosynthetic capability and keepings results contribute to improving photosynthetic capability and keeping higher photosynthesis rates in plants under stress conditions (Makino, 2011). Also, data showed that $\mathrm{Ca}$ sprays significantly affected plant height and head diameter of the sunflower plant. These results caused by improving growth and physiological performance under drought conditions (Xu et al., 2013). Applying salicylic acid with $\mathrm{Ca}$ sprays has given more effective results on the growth parameter of the sunflower plant. This is due to the positive effect of spraying salicylic acid and calcium together. (Figure2) illustrated that the highest results of plant height were obtained with (application of $\mathrm{P} 12+$ zinc foliar +salicylic acid foliar with calcium foliar). This indicated that applying the high rate of $\mathrm{P} 12$ using both salicylic acid and calcium was more effective than the low rate of P6 and using salicylic acid or calcium separately. 
Table 2. Effect of phosphoric acid, zinc spray, and SA spray on plant height (cm) and head diameter(cm) of sunflower plants during two seasons

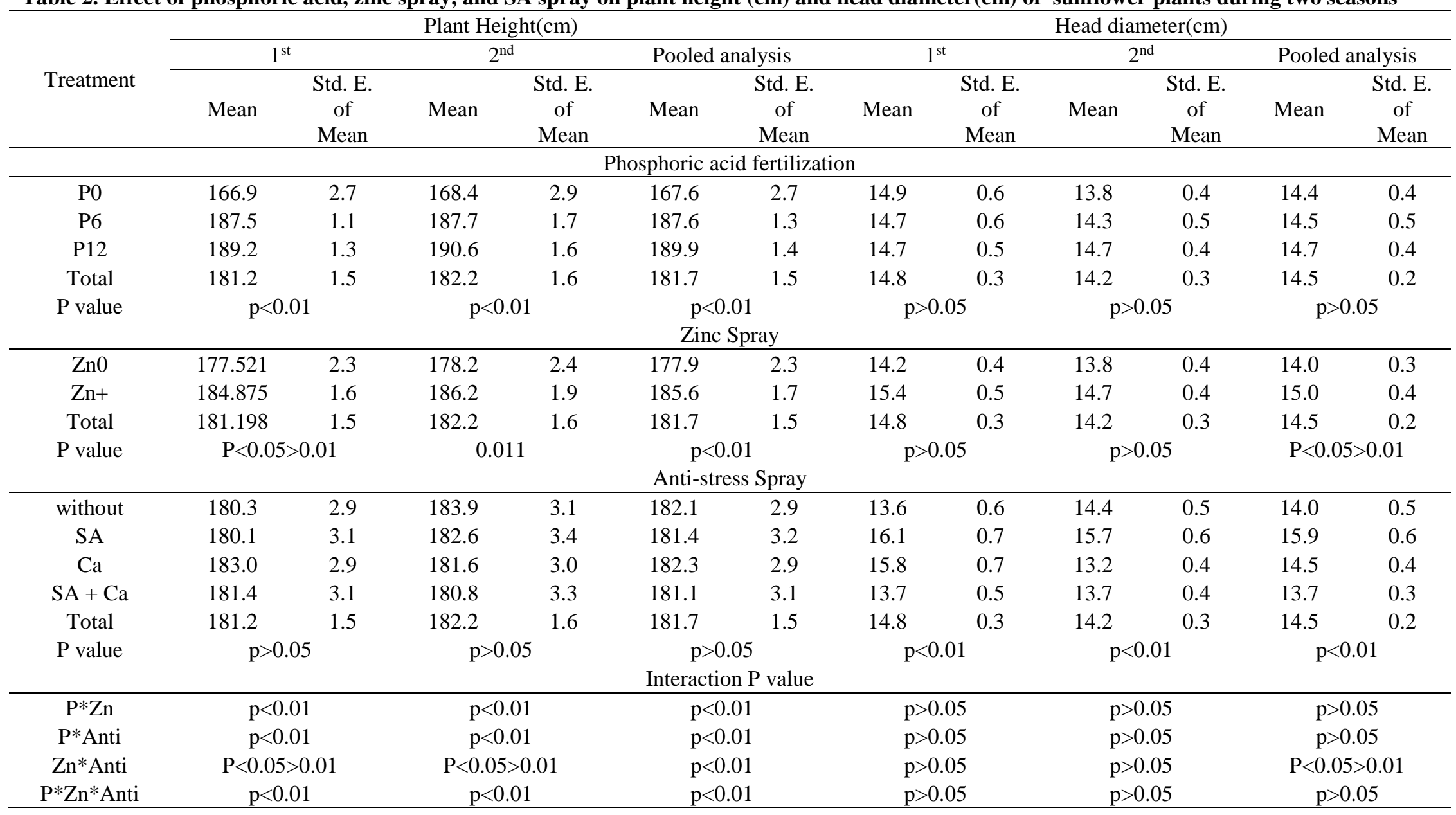




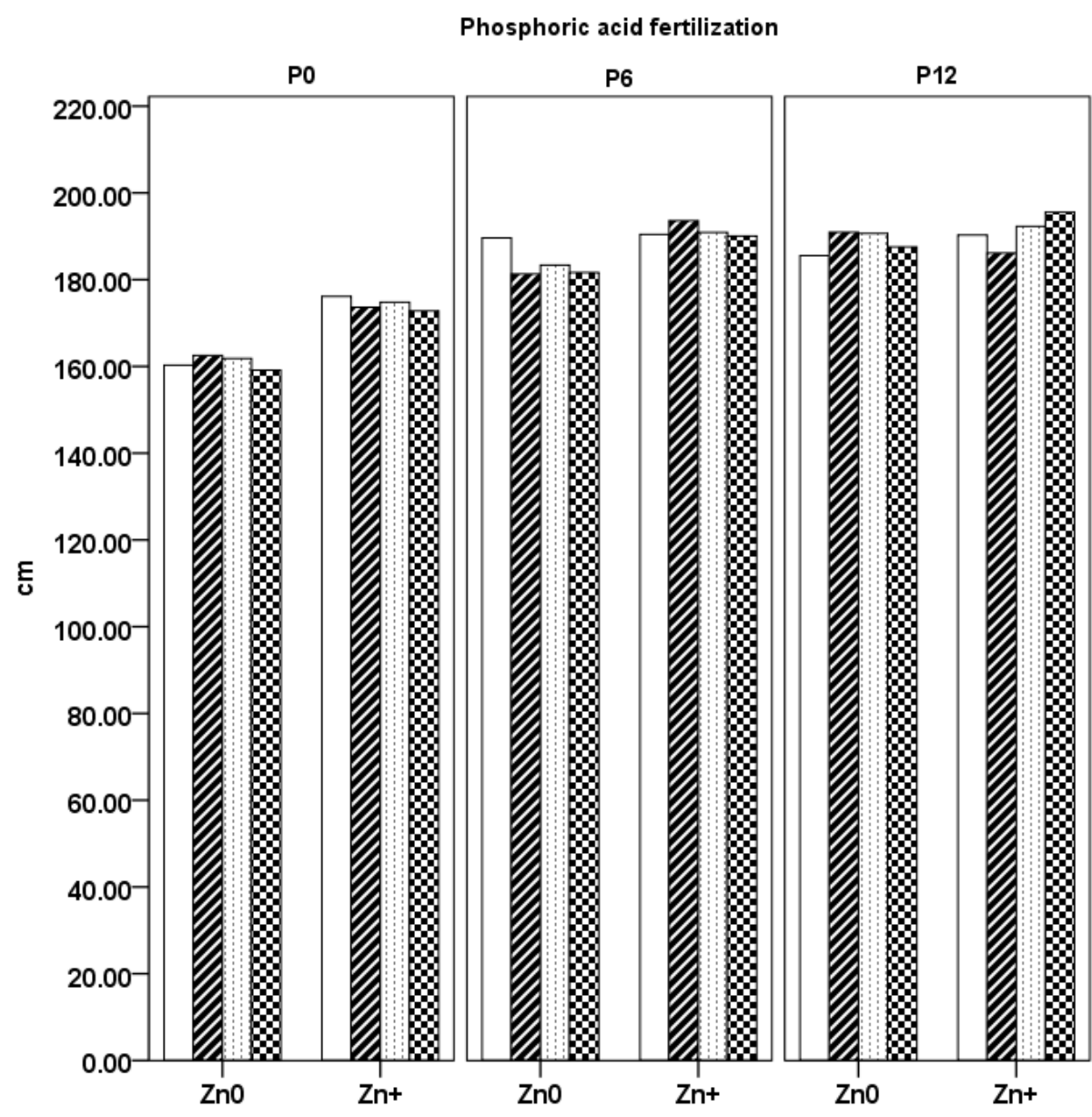

Anti Stess Foliar

$\square$ without

ISA

$\mathrm{Ca}$

$\mathrm{BSA}+\mathrm{Ca}$

Fig 2. Plant height $(\mathrm{cm})$ for sunflower as affected by interaction between (phosphoric acid $\times$ zinc spray $\times$ anti-stress spray) during two seasons 
Table 3. Effect of phosphoric acid, zinc spray, and anti-stress spray on1000-seed weight, seed yield, and oil content in sunflower plant during two seasons

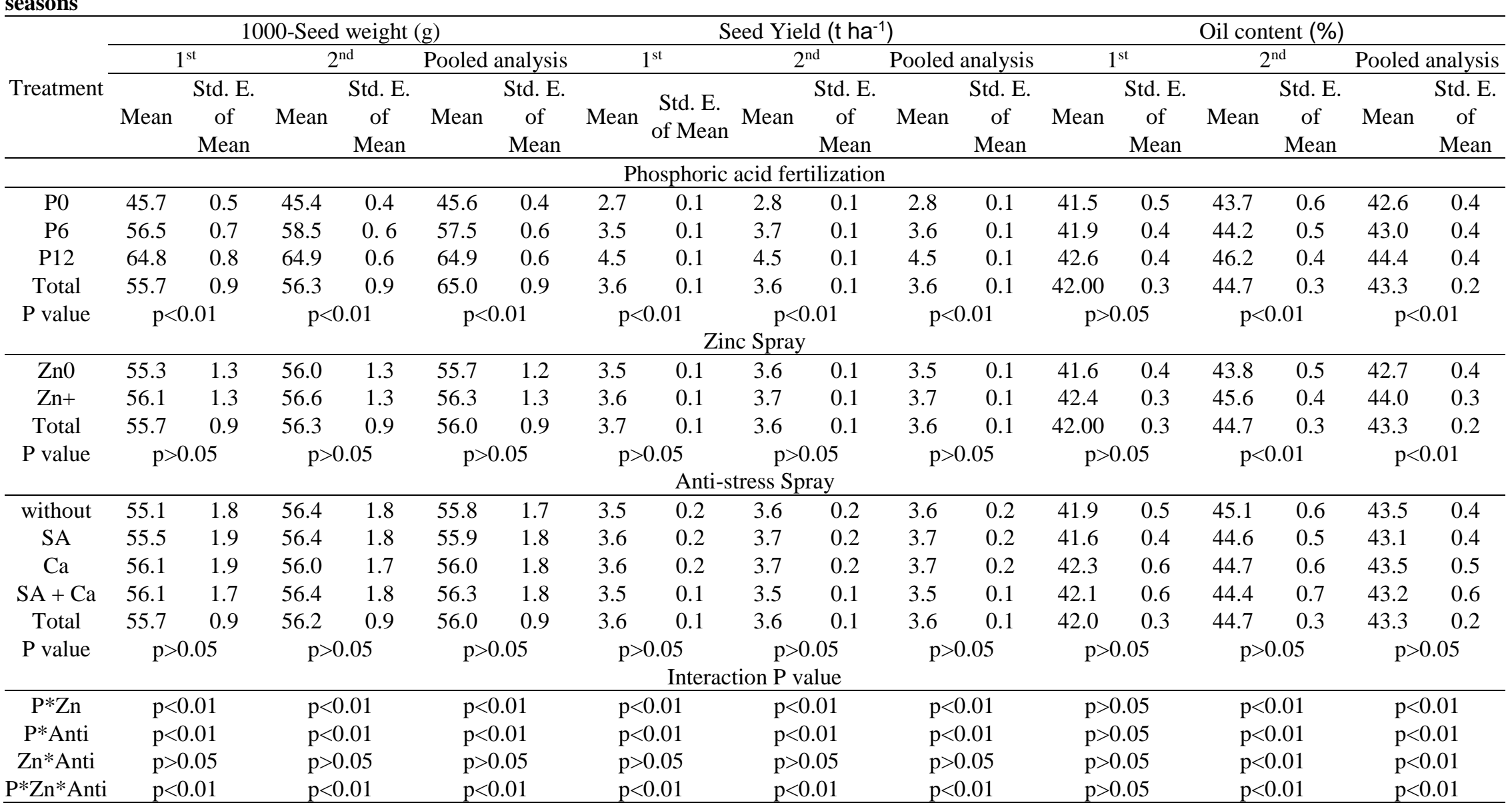




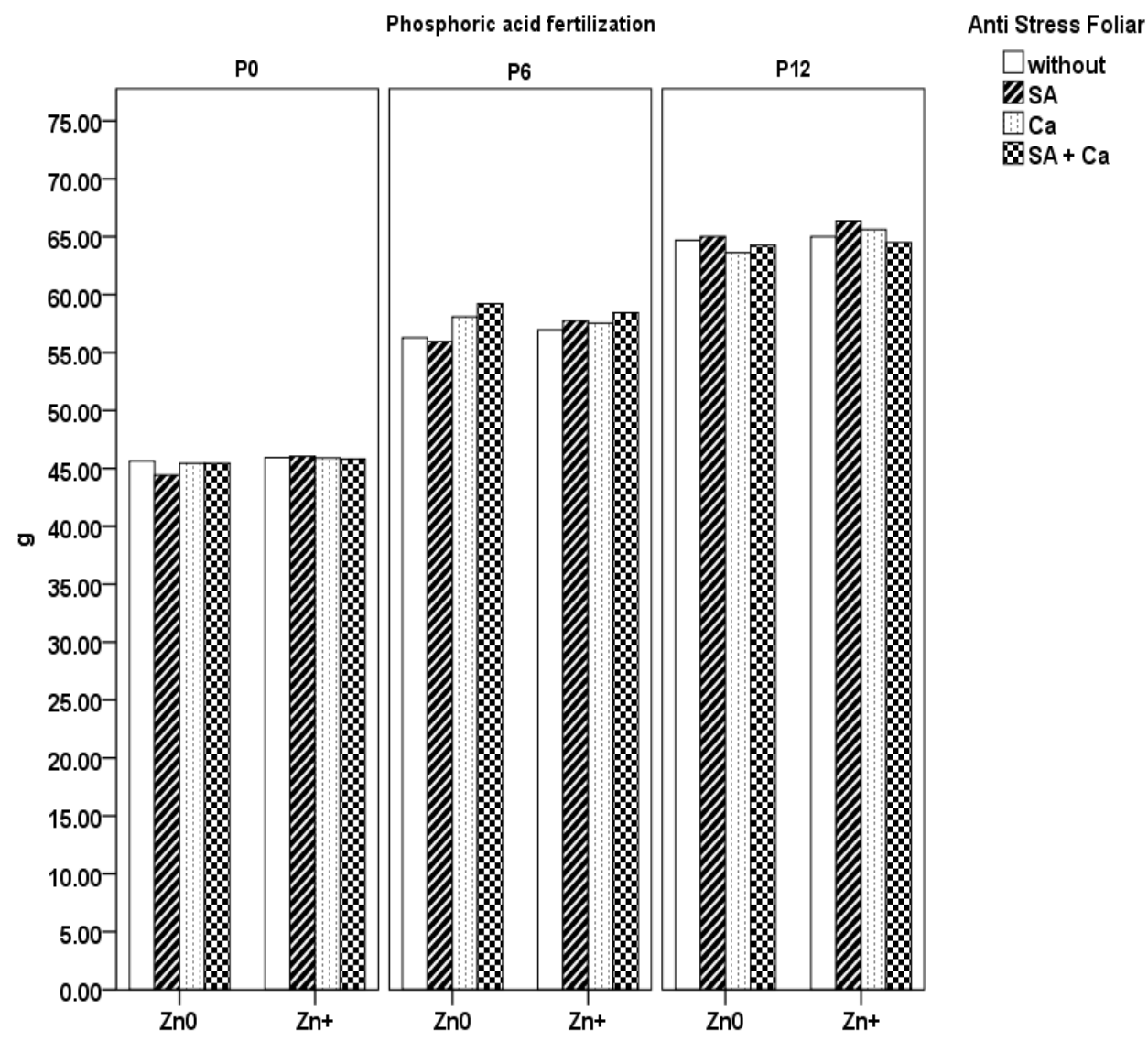

Fig. 3. 1000 seed weight $(g)$ for sunflower as affected by interaction between (phosphoric acid $\times$ zinc spray $\times$ anti-stress spray) during two seasons

\section{Yields and yield attributes characteristics:}

A significant phosphoric acid fertilization outcome treatment was observed for seed yield (Table $3 \mathrm{p}<0.01$ ) in both cropping years and pooled analysis.

Higher seed yield was marked by using P12 (4.505 and $4.522 \mathrm{t} \mathrm{ha}^{-1}$ ) and P6 (3.559 and $3.633 \mathrm{t}$ $\left.\mathrm{ha}^{-1}\right)$ treatments compared to the unfertilized control treatment $\left(2.763\right.$ and $\left.2.834 \mathrm{t} \mathrm{ha}^{-1}\right)$, respectively in both seasons.

Table 3 showed significant $(p<0.01)$ effects on sunflower seed yield in both cropping years and pooled analysis as a result of using Zinc foliar. Indeed, zinc foliar treatment led to the highest sunflower seed yield (3.914 and $3.974 \mathrm{t}$ ha-1) compared to the unfertilized control treatment (3.304 and $3.402 \mathrm{t}$ ha-1), respectively, in two seasons.

Sunflower seed yield was significantly $(\mathrm{p}<0.05>0.01)$. Table 2 indicates that applying anti-stress foliar resulted in height a seed yield in both seasons and pooled analysis. The highest values were obtained by $\mathrm{SA}+\mathrm{Ca}$ (3.986 and $\left.4.065 \mathrm{t} \mathrm{ha}^{-1}\right)$, followed by SA (3.683 and $3.727 \mathrm{t}$ $\left.\mathrm{ha}^{-1}\right)$, and $\mathrm{Ca}$ (3.485 and $\left.3.554 \mathrm{t} \mathrm{ha}^{-1}\right)$ in both seasons, respectively.

As shown in Table 3, a significant interaction $(\mathrm{p}<0.01) \quad$ occurred among phosphoric acid fertilization, zinc foliar, and anti-stress foliar on seed yield and pooled seed yield of sunflower. The highest results of seed yield (Figure 4) were gained with (the application of 12 phosphoric acid fertilization with foliar application of zinc foliar under salicylic acid with calcium spraying), (the application of P12 + salicylic acid with calcium foliar), and (the application of $\mathrm{P} 12+$ zinc foliar + salicylic acid foliar), respectively. It is evident from data shown in Table 3 that there was a significant $(\mathrm{p}<0.01)$ result on the weight of 1000 seed of sunflower plant using phosphoric acid fertilization in both seasons. P12 obtained the 
highest results obtained the highest results then P6 treatment, respectively. Similar results were obtained by applying phosphoric acid fertilization on the pooled weight of 1000-seed the sunflower plant.

Table 3 showed that spraying Zinc on sunflower plant had given a significant $(\mathrm{p}<0.01)$ outcome on the weight of 1000 -seed and pooled analysis in $1^{\text {st }}$ season. Also, significant $(p<0.05>0.01)$ results on these parameters were obtained in $2^{\text {nd }}$ season via using zinc foliar. The highest significant values of the previous parameters were achieved by using Zinc foliar compared to without zinc foliar in both seasons.

Applying anti-stress foliar on sunflower plant resulted in high values on the weight of 1000-seed compared with to without anti-stress foliar (Table $2)$. The effect of anti-stress foliar on the sunflower plant was significant at $(\mathrm{p}<0.05>0.01)$ in $1^{\text {st }}$ season. In the other hand, it was significant at $(\mathrm{p}<0.01)$ on the weight of 1000 -seed in pooled analysis and $2^{\text {nd }}$ season. The highest values were recorded with $\mathrm{SA}+\mathrm{Ca}, \mathrm{SA}$, and $\mathrm{Ca}$, respectively.

Table 3 illustrate a significant interaction $(\mathrm{p}<0.01)$ among phosphoric acid fertilization, Zinc foliar, and anti-stress foliar on the weight of 1000seed and pooled weight of 1000-seed sunflower plant.

The highest results of 1000-seed weight (Figure3) were achieved by (the application of P12 + zinc foliar + salicylic acid with calcium foliar), (the application of P12 + zinc foliar + salicylic acid foliar), and (the application of $\mathrm{P} 12+$ salicylic acid with calcium foliar), respectively.

1000-seed weight and yield of sunflower plant had significantly increased by using phosphoric acid Table 3. This could be attributed to making saline soils better by acidification effect which declining their $\mathrm{pH}, \mathrm{EC}$ and SAR and promoting salts leaching through soil, which improves crop yield in saline soils (Hussain et al., 2011 and Ameen et al., 2019). Additionally, zinc applying significantly increased the 1000 -seed weight and yield of the sunflower plant (Table 3). This could be caused by improving salt stress tolerance by upgrading plant water relations, cell membrane stability, osmolytes concentration, stomata regulation, and water uptake. Furthermore, Zinc is responsible for protein synthesis of pollen tubes and causation protein storage. This leads to an increase in fertility and increased seed yields (Mirzapour and Khoshgoftar 2006; Hatami, 2017 and Hassan et al., 2020). In the same Table, 1000seed weight and products of sunflower plant were affected significantly by anti-stress foliar application. Data in Table 3 showed that salicylic acid significantly affected the yield attribute and yields of the sunflower plant. These results are attributed to the bioregulator effects of salicylic acid on biochemical and physiological processes in plants, increasing resistance against stress conditions (El-Tayeb 2005 and Kishor et al., 2014). Additionally, data illustrated that $\mathrm{Ca}$ spray was affected significantly on 1000-seed weight and yields of the sunflower plant. Indeed, this effect could be connected to declining salt toxicity on sunflower plants (Daowei and Moxin, 2010). Using salicylic acid with $\mathrm{Ca}$ sprays has given more effective results on 1000-seed weight and yields of the sunflower plant. This is due to the positive effect of spraying salicylic acid and calcium on 1000-seed weight and yields. As shown in (Figs 3 and 4). The highest results of 1000-seed weight and seed yield were recorded with (application of P12 + zinc foliar + salicylic acid with calcium foliar). This result indicated that applying high rate of $\mathrm{P} 12$ with using both of salicylic acid and calcium had more effective than low rate of $\mathrm{P} 6$, and using salicylic acid or calcium separately, beside using Zinc foliar which gave the highest 1000-seed weight and seed yield of sunflower plant.

\section{Oil content}

oil content in the sunflower plant was significantly $\quad(p<0.05>0.01) \quad$ increased via phosphoric acid fertilization compared to the control in the $2^{\text {nd }}$ season and pooled analysis (Table 3). But it had a non-significant effect $(p>0.01)$ in the $1^{\text {st }}$ season. Application of P12 resulted in excellent oil \% content in sunflower plant (46.72 and 44.88) then applying p6 (44.67 and 43.51) in the $2^{\text {nd }}$ season and pooled oil \% content, respectively. Oil content in sunflower plants during both seasons and pooled analysis was influenced by zinc foliar application, Table 3 . In general, the $\%$ oil content was significantly $(p<0.01)$ escalated by zinc foliar in the $1^{\text {st }}$ season and pooled \% oil content (44. 54 and 45. 31), respectively. But zinc foliar on oil content had a non-significant $(p>0.01)$ effect in the $2^{\text {nd }}$ season. Table 3 remarks that oil content was significantly $(\mathrm{p}<0.05)$ influenced by anti-stress foliar in both seasons and pooled analysis.

The effect of anti-stress foliar on oil had varied interactions. The highest percentage of oil content was gained by using $\mathrm{SA}+\mathrm{Ca}$ (46.04 and $50.31) \%$, SA (43.41 and 45.94) \% and $\mathrm{Ca}(41.24$ and $43.66 \%$ in both seasons, respectively. 


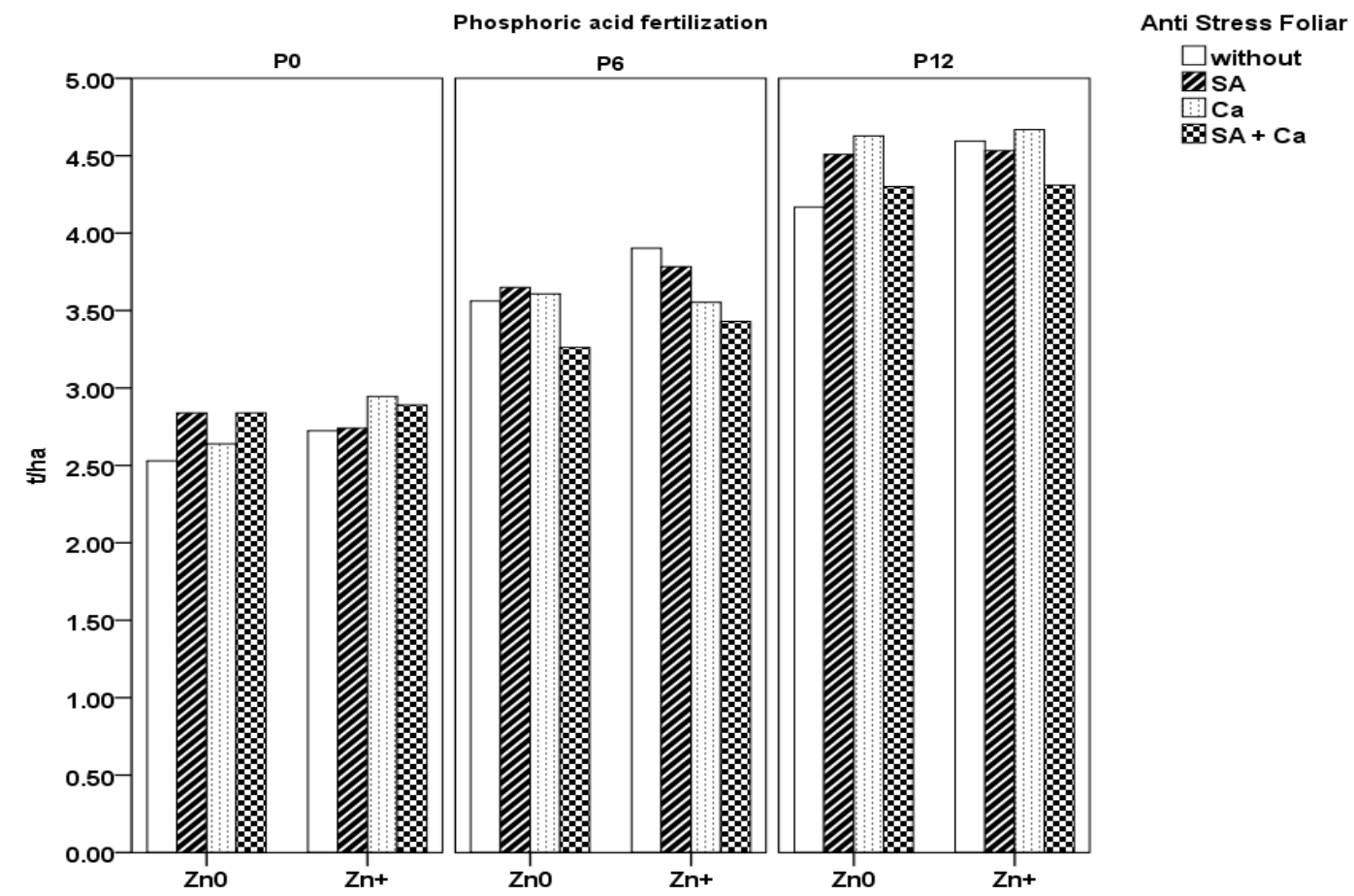

Fig. 4. seed yield $\left(\mathrm{t} \mathrm{ha}^{-1}\right)$ of sunflower as affected by interaction between (phosphoric acid $\times$ zinc spray $\times$ antistress spray) during two seasons

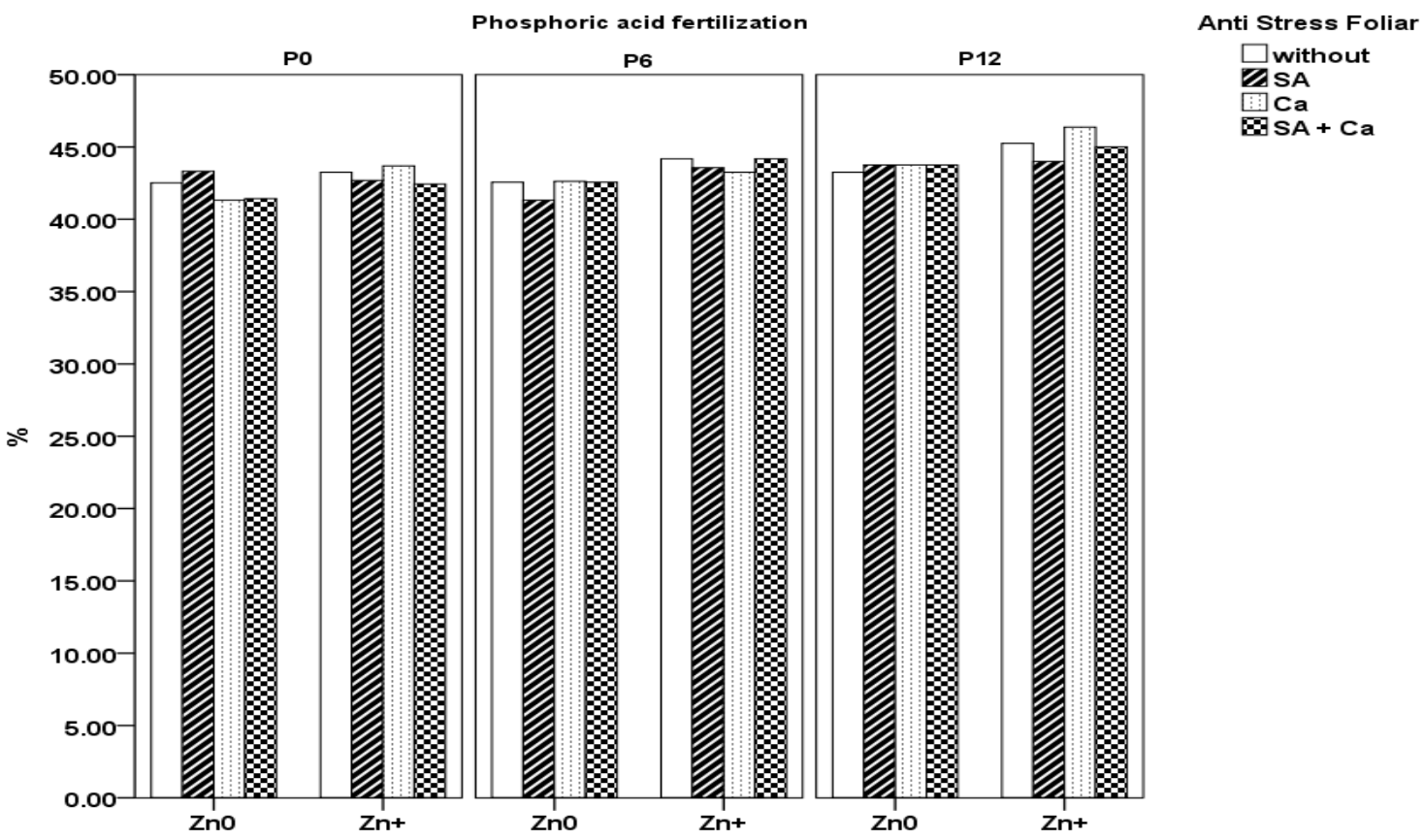

Fig. 5. Oil content $(\%)$ for sunflower as affected by interaction between (phosphoric acid $\times$ zinc spray $\times$ antistress spray) during two seasons 
Table 3 notes a significant interaction $(\mathrm{p}<0.05>0.01)$ between phosphoric acid fertilization, Zinc foliar, and anti-stress foliar on oil content in 2nd and pooled oil content of sunflower plant.

The highest oil content (Fig. 5) were profited with (using P12 + zinc foliar + salicylic acid with calcium foliar), (using P6 + salicylic acid with zinc foliar calcium foliar) and (zinc foliar + salicylic acid with calcium foliar), respectively.

Applying phosphoric acid caused a significant increment in the oil content of the sunflower plant (Table 3). Phosphoric acid caused a relieving salinity negative and improving growth parameter which enhanced sunflower agricultural component and oil yield. (Kaya et al., 2001 and Mahmood et al., 2013). Moreover, applying Zinc foliar significantly increments the oil content $\%$ of the sunflower plant Table 3 . This could be attributed to its effect on growth parameters such as seed weight which increased by zinc foliar. In the same Table, the oil content of the sunflower plant was affected significantly by anti-stress foliar. Table 3 showed that salicylic acid had significantly affected the oil content of the sunflower plant. This result might be due to the increase in vegetative growth and nutrient uptake (Çag et al., 2009). Regarded calcium spray had affected significantly on oil content Table 3 . It is caused by enhancing change under lack of moisture conditions by $\mathrm{Ca}$ foliar. Also, in the same table, applying salicylic acid with $\mathrm{Ca}$ sprays has given more effective results on the oil content of the sunflower plant. This is due to the positive effect of both spraying salicylic acid and calcium together on oil content, as shown in (Figure 5). The highest oil content results were recorded with (application of $\mathrm{P} 12+$ zinc foliar + salicylic acid with calcium foliar). This finding indicated that applying a high rate of P12 with using both salicylic acid and calcium was more effective than a low rate of P6. Using salicylic acid or calcium separately, besides using Zinc foliar gave the highest oil content of the sunflower plant.

\section{Sodium and chloride concentration}

Table 4, showed that the effect of phosphoric acid on ( $\mathrm{Na}$ and $\mathrm{Cl}) \%$ in sunflower plant is nonsignificant $(p>0.05)$ in both seasons and pooled analysis compared to control plants. Also, there is a significant $(\mathrm{p}<0.05)$ reduction in $(\mathrm{Na}$ and $\mathrm{Cl}) \%$ in sunflower plants by the favor of zinc foliar in the $2^{\text {nd }}$ season and pooled analysis. On contrast $\mathrm{Na} \%$ has non-significant $(\mathrm{p}>0.05)$ effect in the $1^{\text {st }}$ season.
During both seasons and pooled analysis Table 4, $(\mathrm{Na}$ and $\mathrm{Cl}) \%$ is significantly $(\mathrm{p}<0.05)$ declined by anti-stress foliar. The effect of anti-stress foliar on $(\mathrm{Na}$ and $\mathrm{Cl}) \%$ has various interactions. The minimum $(\mathrm{Na}$ and $\mathrm{Cl})$ percentage was obtained by using $\mathrm{SA}+\mathrm{Ca}$, SA and $\mathrm{Ca}$ in both seasons and pooled analysis, respectively.

Table 4, shows the significant interaction $(\mathrm{p}<0.05>0.01) \quad$ between phosphoric acid fertilization, zinc foliar, and anti-stress foliar on $\mathrm{Na} \%$ in two seasons and pooled analysis. But there is a non-significant $(\mathrm{p}>0.05)$ result on $\mathrm{Cl} \%$ in two seasons and pooled analysis. The minimum $\mathrm{Na} \%$ content in the sunflower plant (Figure 6) is gained by the (application of P12 + zinc foliar + salicylic acid with calcium foliar), (application of P6 + zinc foliar + salicylic acid with calcium foliar) and (zinc foliar + salicylic acid with calcium foliar), respectively.

From data in Table 4, the effect of phosphoric acid on $(\mathrm{Na}$ and $\mathrm{Cl}) \%$ in sunflower plants was nonsignificant. In the same Table, there was a significant effect on $(\mathrm{Na}$ and $\mathrm{Cl}) \%$ in sunflower plants caused by using zn foliar. zn shortage may influence Na uptake at toxic levels in salt-stressed plants. Accordingly, enhancing $\mathrm{Zn}$ nutritional condition on plant growth could gradually improve its salt stress tolerance. (Mirzapour and Khoshgoftar 2006). Data in Table 4 showed that $(\mathrm{Na}$ and $\mathrm{Cl}) \%$ in sunflower plant were affected significantly by anti-stress foliar. Salicylic acid significantly affected $(\mathrm{Na}$ and $\mathrm{Cl}) \%$ of the sunflower plant by decreasing it. Salicylic acid has affirmed a possible Phyto protectant for declining salinity negative influences. $\mathrm{Na}^{+}$and $\mathrm{Cl}^{-}$ions have been defeated in the plant system (Noreen et al., 2017). Calcium spray had significantly decreased $(\mathrm{Na}$ and $\mathrm{Cl}) \%$ in sunflower plant (Table 4). It is examined that calcium restricts $\mathrm{Na}^{+}$ uptake (Bonilla et al., 2004). Table 4 showed that applying salicylic acid with $\mathrm{Ca}$ sprays has given more effective results on $(\mathrm{Na}$ and $\mathrm{Cl}) \%$ in sunflower plants by reducing it. This is due to the positive effect of spraying salicylic acid and calcium together to decrease ( $\mathrm{Na}$ and $\mathrm{Cl}) \%$ in the sunflower plant, as shown in (Figure 6). The lowest results of $\mathrm{Na} \%$ was recorded with the application of (P12 + zinc foliar + salicylic acid with calcium foliar). This result indicated that applying a high rate of P12 with using both salicylic acid and calcium was more effective than a low rate of P6. Also, using salicylic acid or calcium separately, besides using Zinc foliar gave the lowest $\mathrm{Na} \%$ of the sunflower plant. 
Table 4. Effects of phosphoric acid, zinc spray, and anti-stress spray-on sodium and chloride percentage in sunflower plants during two seasons

\begin{tabular}{|c|c|c|c|c|c|c|c|c|c|c|c|c|}
\hline \multirow{3}{*}{ Treatment } & \multicolumn{6}{|c|}{$\mathrm{Na} \%$} & \multicolumn{6}{|c|}{$\mathrm{Cl} \%$} \\
\hline & \multicolumn{2}{|c|}{$\mathbf{1}^{\text {st }}$} & \multicolumn{2}{|c|}{$2^{\text {nd }}$} & \multicolumn{2}{|c|}{ Pooled analysis } & \multicolumn{2}{|c|}{$\mathbf{1}^{\text {st }}$} & \multicolumn{2}{|c|}{$2^{\text {nd }}$} & \multicolumn{2}{|c|}{ Pooled analysis } \\
\hline & Mean & $\begin{array}{l}\text { Std. E. } \\
\text { of Mean }\end{array}$ & Mean & $\begin{array}{l}\text { Std. E. } \\
\text { of Mean }\end{array}$ & Mean & $\begin{array}{l}\text { Std. E. } \\
\text { of Mean }\end{array}$ & Mean & $\begin{array}{l}\text { Std. E. } \\
\text { of Mean }\end{array}$ & Mean & $\begin{array}{c}\text { Std. E. } \\
\text { of Mean }\end{array}$ & Mean & $\begin{array}{l}\text { Std. E. } \\
\text { of Mean }\end{array}$ \\
\hline \multicolumn{13}{|c|}{ Phosphoric acid fertilization } \\
\hline P0 & 0.07 & 0.001 & 0.08 & 0.00 & 0.07 & 0.00 & 2.09 & 0.06 & 2.14 & 0.07 & 2.12 & 0.06 \\
\hline P6 & 0.07 & 0.001 & 0.07 & 0.00 & 0.07 & 0.00 & 2.07 & 0.05 & 2.11 & 0.05 & 2.09 & 0.05 \\
\hline $\mathrm{P} 12$ & 0.07 & 0.001 & 0.07 & 0.00 & 0.073 & 0.00 & 1.94 & 0.05 & 2.01 & 0.06 & 1.97 & 0.05 \\
\hline Total & 0.07 & 0.001 & 0.07 & 0.00 & 0.074 & 0.00 & 2.03 & 0.03 & 2.09 & 0.03 & 2.06 & 0.03 \\
\hline$P$ value & \multicolumn{2}{|c|}{$\mathrm{p}>0.05$} & \multicolumn{2}{|c|}{$\mathrm{p}<0.01$} & \multicolumn{2}{|c|}{$\begin{array}{c}\mathrm{P}<0.05>0.01 \\
\text { Zinc Spray }\end{array}$} & \multicolumn{2}{|c|}{$p>0.05$} & \multicolumn{2}{|c|}{$p>0.05$} & \multicolumn{2}{|c|}{$\mathrm{p}>0.05$} \\
\hline $\mathrm{Zn0}$ & 0.07 & 0.001 & 0.08 & 0.00 & 0.075 & 0.001 & 2.08 & 0.05 & 2.13 & 0.05 & 2.11 & 0.05 \\
\hline $\mathrm{Zn+}$ & 0.07 & 0.001 & 0.07 & 0.00 & 0.073 & 0.001 & 1.99 & 0.04 & 2.04 & 0.04 & 2.02 & 0.03 \\
\hline Total & 0.07 & 0.001 & 0.07 & 0.00 & 0.074 & 0.000 & 2.03 & 0.032 & 2.09 & 0.03 & 2.06 & 0.03 \\
\hline$P$ value & \multicolumn{2}{|c|}{$\mathrm{p}<0.01$} & \multicolumn{2}{|c|}{$\mathrm{P}<0.05>0.01$} & \multicolumn{2}{|c|}{$\begin{array}{c}\mathrm{p}<0.01 \\
\text { Anti-stress Spray }\end{array}$} & \multicolumn{2}{|c|}{$p>0.05$} & \multicolumn{2}{|c|}{$\mathrm{p}>0.05$} & \multicolumn{2}{|c|}{$\mathrm{p}>0.05$} \\
\hline without & 0.074 & 0.00 & 0.08 & 0.00 & 0.07 & 0.001 & 2.00 & 0.04 & 2.10 & 0.06 & 2.05 & 0.05 \\
\hline SA & 0.072 & 0.00 & 0.08 & 0.00 & 0.07 & 0.001 & 2.09 & 0.06 & 2.12 & 0.06 & 2.10 & 0.06 \\
\hline $\mathrm{Ca}$ & 0.074 & 0.00 & 0.07 & 0.00 & 0.07 & 0.001 & 2.06 & 0.07 & 2.09 & 0.08 & 2.07 & 0.08 \\
\hline $\mathrm{SA}+\mathrm{Ca}$ & 0.071 & 0.00 & 0.07 & 0.00 & 0.07 & 0.001 & 2.00 & 0.07 & 2.04 & 0.07 & 2.02 & 0.07 \\
\hline Total & 0.073 & 0.00 & 0.07 & 0.00 & 0.07 & 0.000 & 2.03 & 0.03 & 2.09 & 0.03 & 2.06 & 0.03 \\
\hline $\mathrm{P}$ value & \multicolumn{2}{|c|}{$p>0.05$} & \multicolumn{2}{|c|}{$\mathrm{p}>0.05$} & \multicolumn{2}{|c|}{$\begin{array}{l}\quad \mathrm{p}>0.05 \\
\text { Interaction } \mathrm{P} \text { value }\end{array}$} & \multicolumn{2}{|c|}{$\mathrm{p}>0.05$} & \multicolumn{2}{|c|}{$\mathrm{p}>0.05$} & \multicolumn{2}{|c|}{$\mathrm{p}>0.05$} \\
\hline $\mathrm{P} * \mathrm{Zn}$ & \multicolumn{2}{|c|}{$\mathrm{p}>0.05$} & \multicolumn{2}{|c|}{$\mathrm{p}<0.01$} & \multicolumn{2}{|c|}{$\mathrm{P}<0.05>0.01$} & & .05 & & .05 & & .05 \\
\hline P*Anti & & .05 & & .01 & $\mathrm{P}<0$. & $>0.01$ & & .05 & & .05 & & .05 \\
\hline Zn*Anti & & .01 & & .05 & & 01 & & .05 & & .05 & & .05 \\
\hline $\mathrm{P} * \mathrm{Zn} * \mathrm{Anti}$ & & .05 & & .01 & $\mathrm{P}<0$. & $>0.01$ & & .05 & & .05 & & .05 \\
\hline
\end{tabular}




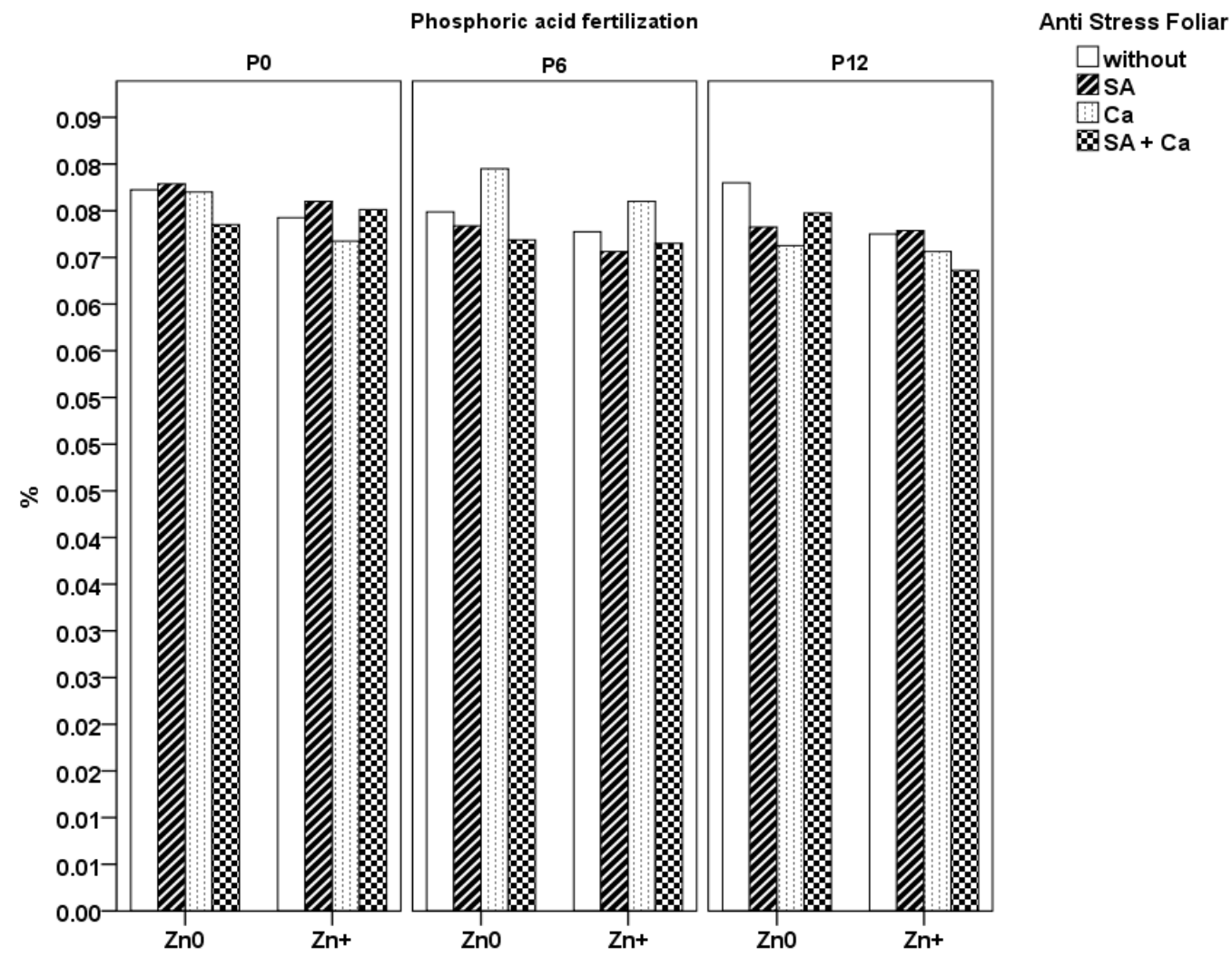

Fig. 6. Na (\%) of sunflower as affected by the interaction between (phosphoric acid $\times$ zinc spray $\times$ anti-stress spray) during two seasons

\section{CONCLUSION}

The results indicate that although the effect of salinity on the sunflower plant negatively, it was possible to resist this harmful effect by using phosphoric acid, zinc spray, salicylic acid spray, and calcium spray. Where the interaction among these treatments showed that using phosphoric acid $\left(12 \mathrm{~L} \mathrm{ha}^{-1}\right)$ acid with zinc spray (at $13 \%$ chelated on EDTA) and spraying both salicylic acid $(0.01 \mathrm{mM}$ ) and calcium (at $10 \%$ chelated on EDTA), together showed an effective impact on increasing growth, the yield of seeds, oil content and resisting salinity by reducing the concentration of sodium and chloride in the plant.

\section{Recommendation}

From the results obtained, we recommend that using phosphoric (12 $\left.\mathrm{L} \mathrm{ha}^{-1}\right)$ acid with zinc spray (at $13 \%$ chelated on EDTA) and spraying both salicylic acid $(0.01 \mathrm{mM})$ and calcium (at $10 \%$ chelated on EDTA), more effective in increasing the resistance to salinity by getting an economic yield and reducing the concentration of the element's sodium and chloride in sunflower plant.

\section{Acknowledgments}

The authors declare that they have no conflicts of interest. They would also like to thank the research members of El-Serw Agricultural Research Station for assistance in field experiments and laboratory analyzes.

\section{REFERENCES}

A.O.A.C. 1980. Official methods of analysis. 14th edition Association of official analytical chemists Washington, D. C, USA.

Abd El- Hammeid, A.R and M.S. Sadak. 2020. Impact of glutathione on enhancing sunflower growth and biochemical aspects and yield to alleviate Salinity stress. Biocatal. Agric. Biotechnol. 29101744.

Aktas, H., K. Abak, L. Ozturk and I. Cakmak. 2006. The effect of Zinc on growth, and shoot concentrations of sodium and potassium in pepper plants under salinity stress. Turk. J. Agric. For. 30407-412. 
Ali, E., A. Maodzeka, N, Hussain, I, Haider and L. X. Jiang. 2014. The alleviation of cadmium toxicity in oilseed rape (Brassica napus): by the application of salicylic acid. Plant Growth Regul. 75 (3): 641-655.

Ameen, M., J. Akhtar, M. Sabir and R, Ahmad. 2019. Effect of phosphoric acid and potassium humate on growth and yield of maize in saline-sodic soil. Pak. J. Agric. Sci.. 56 (4): 781-790.

Bonillaet, I., A, El-Hamdaoui and L. Bolanos. 2004. Boron and calcium increase pisum sativum seed germination and seedling development under salt stress. Plant Soil. 267 (1):97-107.

Cag, S., G. Cevahır-oz, M, Sarsag and N. Goren-Saglam. 2009. Effect of salicylic acid on pigment, protein content and peroxidase activity in excised sunflower cotyledons. Pak. J. Bot. 41 (5): 2297-2303.

Chapman, H.D and P. F. Pratt. 1961. Methods of analysis for soil, plant and water. Riverside, CA University of California. Division of Agriculture Science.

Connor, D.J and A. J. Hall.1997. Sunflower physiology. In schneiter, A. A. (Ed.), sunflower technology and production. American Society of Agronomy, Madison, WI, USA, p. 113-182.

Daowei, Z and X. Moxin. 2010. Specific ion effects on the seed germination of sunflower. J. Plant Nutr. 33 (2): 255-266.

Dawood, M.G., M.S. Sadak and M. Hozayen. 2012. Physiological role of salicylic acid in improving performance, yield and some biochemical aspects of sunflower plant grown under newly reclaimed sandy soil. Aust. J. Basic Appl. Sci. 6 (4): 82-89.

Elkhatib, H.A., S.M. Gabr, A.H. Roshdy and M.M. Abd AlHaleem. 2017. The Impacts of Silicon and Salicylic Acid Amendments on Yield and Fruit Quality of Salinity Stressed Tomato Plants. Alex. Sci . Exch. J. 38: 933-939.

El-Tayeb, M.A. 2005. Response of barley grains to the interactive effects of salinity and salicylic acid. Plant Growth Regul. 45 (3): 215-224.

Hassan M. U., M. Aamer, M.U. Chattha, T. Haiying, B. Shahzad, L. Barbanti, M. Nawaz, A. Rasheed, A. Afzal, Y. Liu and H. Guoqin. 2020. The critical role of Zinc in plants facing the drought stress. Agric. 10 (9): 396.

Hatami, H. 2017. The effect of zinc and humic acid applications on yield and yield components of sunflower in drought stress. J. Adv. Agric. Technol. 4 (1): 36-39.

Hussain, F., M. Akhtar, M.Y. Ashraf, T.M. Qureshi, A. ul-Haq and A. Naeem. 2011. Evaluation of phosphoric acid as a phosphate fertilizer for wheat production on salt-affected soils. Agrochimica. 5 (1): 203-211.

Jackson, M. L. 1967.Soil chemical analysis. Prentice-Hall of india, New Delhi.

James, R., I.C. Blake, C.S. Byrt and R. Munns. 2011. Major genes for $\mathrm{Na}+$ exclusion, Nax1 and Nax2 (wheat HKT1; 4 and HKT1; 5): decrease $\mathrm{Na}+$ accumulation in bread wheat leaves u saline and waterlogged conditions. J. Exp. Bot. 62 (8): 2939 - 2947.
Kaya, C., H. Kirnak and D. Higgs. 2001. Enhancement of growth and normal growth parameters by foliar application of potassium and phosphorus in tomato cultivars grown at high $(\mathrm{NaCl})$ : salinity. J. Plant Nutr. 24 (2): 357-367.

Kishor, P.B.K., K. Rajesh, P.S. Reddy, C. Seiler and N. Sreenivasulce. 2014. Drought stress tolerance mechanisms in barley and its relevance to cereals. in biotechnological approaches to barley improvement, Kum., J. Stein, N. (eds). Springer, Berlin.161-179.

Mahmood, I.A., A. Ali, M. Aslam, A. Shahzad, T. Sultan and F. Hussain. 2013. Phosphorus availability in different saltaffected soils as influenced by crop residue incorporation. Int. J. Agric. Biol . 15 (3): 472-478.

Makino, A. 2011. Photosynthesis, grain yield, and nitrogen utilization in rice and wheat. Plant Physiol. 155 (1): 125129.

Mirzapour, M.H and A.H. Khoshgoftar. 2006. Zinc Application effects on yield and seed oil content of sunflower grown on a saline calcareous soil. J. Plant Nutr. 29 (10): 1719-1727.

Nelson, D.W and L. E. Sommers.1980. Total nitrogen analysis of soil and plant tissues. J. AOAC Int. 63, 770778. doi 101093/jaoac/634770.

Noreen, S., H.R. Athar and M. Ashraf. 2013. Interactive effects of watering regimes and exogenously applied osmoprotectants on earliness indices and leaf area index in cotton Gossypium hirsutum L. crop. Pak. J. Bot. 45 (6): 1873-1881.

Noreen, S., A. Siddiq, K. Hussain, S. Ahmad and M. Hasanuzzaman. 2017. Foliar application of salicylic acid with salinity stress on physiological and biochemical attributes of sunflower (Helianthus annuus L.) Cr. Acta Sci. Pol. Hortorum Cultus. 16 (2): 57-74.

Olsen, S.R., C.V. Cole, F.S. Waternabe and L.A. Dean. 1954. Estimation of available 6 phosphorus in soil by extraction with sodium bicarbonate. USDA

Quader, A.K.M.A. 2009. Strategy for developing the fertilizer sector in Bangladesh for sustainable agriculture. Chem. Eng. Res. Bull. 13 (2): 39-46.

Raghothama, K.G and A.S. Karthikeyan. 2005. Phosphate acquisition. . Plant Soil. 274, 37-49

Rasool, S., A. Ahmad, T.O. Siddiqui and P. Ahmad. 2013. Changes in growth, lipid peroxidation and some key antioxidant enzymes in chickpea genotypes under salt stress. Acta Physiol. Plant. 35 (4): 1039-1050.

Snedecor, G.W and W.G. Cochran. 1981. Statistical methods. $7^{\text {th }}$ ed. USA Iowa State University Press.

Szabados, L and A. Savoure. 2010. Proline A multifunctional amino acid. Trends Plant Sci. 15 (2): 89-97.

Soares, B.E., A. P. B. Junior, J. R. T. de Albuquerque, M. G. dos Santos, H. A. Lins and F. B. Neto. 2020. Sunflower performance as a function of phosphate fertilization in semi-arid conditions. Acta Sci. Agron. 42. 
Tsonev, T and F. J. C. Lidon. 2012. Zinc in plants-An overview. Emir. J. Food Agric. 24 (4): 322-333.

Wojcik, P., H. Akgul, I. Demirtaş, C. Sarısu, M. Aksu and H. Gubbuk. 2013. effect of preharvest sprays of calcium chloride and sucrose on cracking and quality of burlat sweet cherry fruit. J. Plant Nutr. 36 (9): 1453-1465
Xu, C., X. Li and L. Zhang. 2013. The effect of calcium chloride on growth, photosynthesis, and antioxidant responses of Zoysia japonica under drought conditions. PLoS One. 8, e68214.

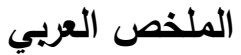

مقاومة الملوحة لنبات عباد الثمس عن طريق استخدام بعض المواد المقاومة للإجهاد والرش بالزنك تحت التسميا مع الرى بحمض الفوسفوريك

أيمن حاكم إبراهيم سراج ، على كمال سعدة ، رانيا محمد الصامت

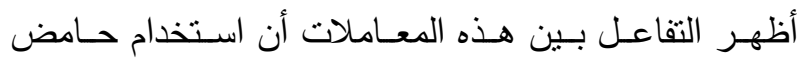
الفوسفوريك (r ا لتر هكتار -1)، مع رش الزنك (زنك مخلبى

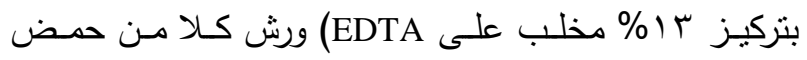

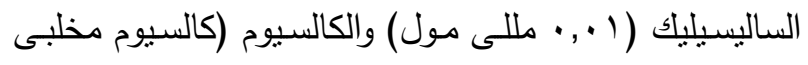
بتركيز • (\% مخلب على EDTA)) معًا تاثيرا فعالا في زيادة النمـو، ومحصـول الحبـوب، ونسـبة المئويـة للزيــ، ومقاومـة الملوحة عن طريق نقليل نركيز الصوديوم ،والكلوريد في نبات عباد الثمس.

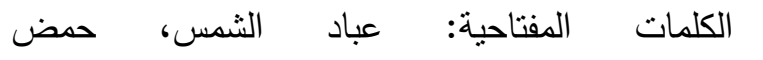
الفوسفوريك،الزنك،حمض السالسليك، الكالسيوم
أجريت تجربتان حقليتان فى تربـة طينية ملحية، حيث تم

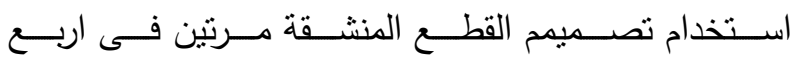
مكررات.تمثل حامض الفوسفوريك فى القطع الرئيسة باضافته مـع مياه الرى بمعدل (7 لتر هكتار -' و با لتر هكتار -1) كوتم استخدام الرش بالزنك في القطع التحت رئيسـة بمعدل (زنك مخلبى بتركيز سا \% مخلب على EDTA) ، وتم الرش ببعض المواد المقاومة للاجهاد فى القطع التحت تحت رئيسـة

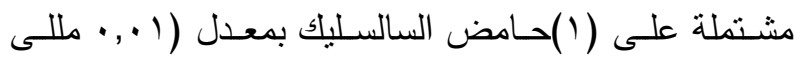

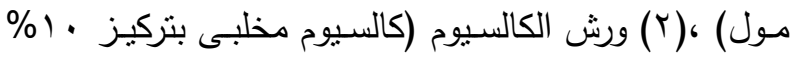

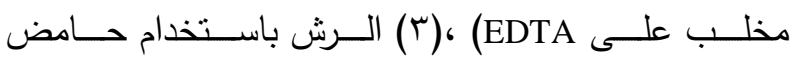
السالسـليك والكالسـيوم معـا بـنفس المعـلات السـابقة. حيـث 